\title{
FAMILY LAW \& ISSUES RELATING TO MARRIAGE : SPECIAL REFERENCE WITH NON RESIDENT INDIAN AND MIGRANTS
}

\author{
Dr. Kaushik C. Raval \\ Dr. Anand Kumar Tripathi
}

\section{- Introduction:}

There are certain laws which are applicable in a territory to all persons irrespective of their caste, creed or race and religion e.g. Law of contract, Criminal Law and Law of Contract etc. Therefore, under general law there is uniformity in the applicability but under family law it's not the law of the place or locality. Wherever a person goes he/she goes with their personal law.

Areas of family law in which the problems of jurisdiction are seen Occurring very frequently relate to dissolution of marriage, inter-parental child abduction, inter country child adoption and succession of property of non-resident Indians. In matters of divorce, since irretrievable breakdown of marriage is not a ground for dissolving the marriage under Indian law, Indian Courts in principle do not recognise foreign matrimonial judgments dissolving marriage by such breakdown. Surprisingly, even very little help is available in areas of matrimonial offences and problems arising out of child abduction. Leaving a helpless deserted Indian spouse on Indian shores confronted with a matrimonial litigation of a foreign court which he or she neither has the means or ability to invoke often results in despair, frustration and disgust. Likewise, enforcement of a foreign court order in whose violation a child of the family has been removed and brought to Indian soil brings a parent to India desperately seeking a legal remedy.

With the increase in the Indian Diaspora and consequently overseas marriage the number of matrimonial and related disputes in such manner has also risen proportionately and at the some places much more than proportionately. Such marriages are not only governed by the Indian legal system but also by the far more complex and delicate rules of Private International Law. ${ }^{1}$

1 A guidance Booklet Marriage to Overseas Indians(2007)p.10 
As it is well known that Indian civilization and cultural heritage is one of the oldest in the world. We as an Indian generally follows, prem-love, daya-pity, dan-charity, anukampa-passionsympathy. There were and are many instances in history. Many foreigners were attracted and came to India to learn and be busy with trade and try to find out route towards India via sea. When man started to live with jointly and family system established and gradually developed. We have our own custom and it's vary with cast to cast and region to region in our own country. But family relation and some other things like, place of birth, religion, education, income, gotra, areas were taken in to consideration for marriage. Because marriage is a pious institute which is meant for spiritual salvation and it is submitted that without marriage no person can be an absolute.

\section{- Mobilization:}

Due to advent of technology in $21^{\text {st }}$ century migration took place in large scale from India to aboard and vise versa. Our nation also settled down in other countries due to economic development and other sophistications.

\section{- $\quad$ Legal Institutions:}

There is variety in diversity of India. Person belonging from various communities having their own personal laws and laws are quite enough to resolve an individual's issue amicably. As we are aware of that every country has its own legal system for mitigation of dispute through legal procedure. Same way there is no system at international level, because each country is sovereign and independent. Law of the country has command and backed by sentences if not followed. But one country's law will not applicable in other country and even cannot be imposed. At international level we have international law, through consensus and treaties. There are two type of international law namely, Public International Law and Private International Law. Public International Law affects State function where as Private International Law has concern with individual who resides across the border of mother-land. Now a day worldwide movement started to promote private international law.

\section{- Civil law, Criminal Law and Personal laws.}

In India we are sovereign and secular where Constitution of India provides freedom of religion which is one of the fundamental rights. We have many branches of adjudications; Criminal Law and Civil Law.

Generally, criminal law of any country is applicable to all within the territorial jurisdiction of the country. But in civil law applies only in matter relating to marriage, adoptions, succession and divorce .Personal Laws in our country are governed as per religion i.e. Hindu, Muslim, Parsi and Christian. 
Here, it would be pertinent to discuss the relevance of "The foreign Marriage Act , 1969" which shall be applicable to marriages of citizens of India outside of India. This law has made every provision of marriage to tackle the issues relating to the persons who solemnised marriage outside India. In case where enormity of problems is faced by either party how solution will be made. On that point this Act has no teeth to ensure the efficacy of Foreign Marriage Act.

Situation is still pathetic in regard to the marriage of NRI/PIO. Law commission of India has been suggesting its views on the said points from time to time. In this regard, the Law Commission of India in 2009 advocated the need for family law legislation for NRIs. The Commission suo moto took up this study and made the following recommendations : “(a) Registration of marriages must be made compulsory; (b) dissolution of marriage on the ground of irretrievable breakdown of marriage be introduced in the Hindu Marriage Act, 1955 and the Special Marriage Act, 1954; (c) Where one of the spouses is an NRI, parallel additions must be made in the Hindu Marriage Act, 1955 and the Special Marriage Act, 1954 to provide for provisions for maintenance and alimony of spouses, child custody and child support and as also settlement of matrimonial property."2

\section{- Cultural and Economic aspect:}

When Indian origin settled in foreign and their son/daughter grows and reach at the age of marriage, they come to know that by their experience and observances that, due to different type of ideology, their way of life, is not consonance with Indian culture. Finally they come to mother-land for marriage of their younger ones.

\section{- $\quad$ Marriage is pious Institution of Society.}

Over the years the problems of Indian women trapped in fraudulent marriages with overseas Indians are increasingly reported. This has underscored the urgent need to build safeguards to protect these women and make them aware of their rights and responsibilities on the one hand and about the safety nets and social defense mechanisms that are available and which could assist them. The problem is manifold and includes dowry and other kinds of harassment of married women in foreign countries like non-consummation of marriages, marriages of convenience, concealment of earlier existing marriage by the husband before marrying an Indian woman and lack of social security faced by an Indian woman on the foreign soil once the marriage is broken and ex parte divorces are obtained. A most conspicuous disturbing trend, however, appears to be the easy dissolution of such marriages by the foreign courts even though their solemnization took place in India as per the Indian laws. Since there is no comprehensive and special law to govern such

2 http://niti.gov.in/content/nri-non-reliable-indian-grooms-ACCESSED ON 5/5/2017 
aspects and also in view of the jurisdictional issues involved in decide the matrimonial cases, women are being deprived of justice with impurity. Though matrimonial disputes are one of the most challenging and delicate areas for legal intervention within any system, what makes the situation complex particularly in the Indian context is the fact that in the absence of uniform civil laws, the personal laws of various religious communities continue to be different, thus making the matrimonial disputes, especially in inter-religious marriages, even more difficult to deal with. In this already complex scenario, the legal complications get multiplied manifold when a marriage steps beyond the borders of a country and its legal system, in a phenomenon that has come to be known as "NRI marriages". These marriages have to then enter the domain - often called the 'maze' - of private international law that deals with the interplay and conflict of laws of different countries, which makes the issues therein that much more complex. Even though this is a genderneutral term, typically the 'NRI marriages', as generally understood, are between an Indian woman from India and an Indian man residing in another country (thus NRI - non-resident Indian), either as Indian citizen(when he would legally be an 'NRI') or as citizen of that other country (when he would legally be a PIO - person of Indian origin). With the characteristic Indians' penchant for migration to foreign countries, such alliances are seen as the most coveted ones in Indian society, promising greener pastures for not just the woman but her entire family. In the eagerness not to let go of such a match, the families totally ignore even the common cautions, that are observed in traditional matchmaking. They also ignore that in case of things going awry in an NRI marriage, the woman's recourse to justice is greatly constrained by the reason that such marriage are not governed any more by only the Indian legal system but by the far more complex private international laws involving the legal system of the other country too. They even ignore the plain and simple fact that just logistically for a woman to negotiate her way to justice across thousands of miles would be a thoroughly exasperating experience. The aggravated risks in such marriages, the woman being isolated far away from home in an alien land, inevitably facing constraints of language, communication, lack of knowledge of local criminal justice, police and legal system, lack of support network of friends and family to turn to, lack of immediate and readily available monetary support and a place to take shelter in, are issues that no one likes to talk or hear about at the time of marriage. It is therefore hardly surprising that there is growing evidence by incidents today that even as the number of NRI marriages is escalating by thousands every year, with the increasing Indian Diaspora, the number of matrimonial and related disputes in the NRI marriages have also raised proportionately, in fact at most places much more than proportionately. 


\section{- Common Issues In NRI Marriages}

Some of the typical instances of the issues that arise in NRI marriages that have been repeatedly reflected in the actual case studies from different states of the country are as follows:

1) Woman married to NRI was abandoned even before being taken by her husband to the foreign country of his residence. After a short honeymoon he had went back, promising to soon send her ticket that never came. In many instances the woman would already have been pregnant when he left and so both she and the child (who was born later) were abandoned. The husband never called or wrote and never came back again. The in-laws who could still be in India would either plead helplessness or flatly refuse to help.

2) Woman went to her husband's home in the other country only to be brutally battered, assaulted, abused both mentally and physically, malnourished, confined and ill-treated by him in several other ways. She was therefore either forced to flee or was forcibly sent back. It could also be that she was not allowed to bring back her children. In many cases, the children were abducted or forcibly taken away from the woman.

3) Woman who was herself or whose parents were held to ransom for payment of huge sums of money as dowry, both before and after the marriage, making her continued stay and safety in her husband's country of residence dependent on that.

4) Woman who reached the foreign country of her husband's residence and waited helpless at the international airport there only to find that her husband would not turn up at all.

5) Woman who was abandoned in the foreign country with absolutely no support or means of sustenance or escape and without even the legal permission to stay on in that country.

6) Woman who learnt on reaching the country of her NRI husband's residence that he was already married in the other country to another woman, whom he continued to live with. He may have married her due to pressure from his parents and to please them or sometimes even to use her like a domestic help or pick up dowry.

7) Woman who later learnt that her NRI husband had given false information on any or all of the following: his job, immigration status, earning, property, marital status and other material particulars, to con her into the marriage.

8) Woman whose husband, taking advantage of more lenient divorce grounds in other legal systems, obtained ex-parte decree of divorce in the foreign country through fraudulent representations and/ or behind her back, without her knowledge, after she was sent back or forced to go back to India or even while she was still there. 
9) Woman who was denied maintenance in India on the pretext that the marriage had already been dissolved by the court in another country.

10) Woman who approached the court, either in India or in the other country, for maintenance or divorce but repeatedly encountered technical legal obstacles related to jurisdiction of courts, service of notices or orders, or enforcement of orders or learnt of the husband commencing simultaneous retaliatory legal proceeding in the other country to make her legal action

11) Woman who sought to use criminal law to punish her husband and in-laws for dowry demands and/ or, or matrimonial cruelty and found that the trial could not proceed as the husband would not come to India and submit to the trial or respond in any way to summons, or even warrant of arrest.

12) Woman who was coaxed to travel to the foreign country of the man's residence and get married in that country, who later discovered that Indian courts have even more limited jurisdiction in such cases.

13) Woman who had to fight nasty legal battles for custody of her children and for child support, and to bring them back with her after she was divorced or forced to leave, sometimes even facing charges of illegally abducting her own children.

\section{- The Role of NCW on NRIs issue:}

The National Commission for Woman was nominated as the Coordinating agency at the National level for dealing with issues pertaining NRI marriages, by Government of India vide Ministry of Overseas Indian Affairs order dated 28th April $2009^{3}$. In furtherance of this, the NRI Cell was formally inaugurated on the 24th of September, 2009. NRI Cell deals with complaints received from India and abroad resulting from cross country marriages wherein there is any deprivation of women's rights or any issue involving grave injustice to women. Since its inception around 515 cases have been registered till 31st December 2010, in the NRI Cell. By this cell it helps to the masses that are aggrieved.

\section{- $\quad$ Role and Function of NRI Cell of NCW}

a) NRI Cell is the coordinating agency to receive and process all the complaints related to Indian Women deserted by their Overseas Indian husbands.

b) NRI Cell renders all possible assistance to the complaints including conciliation, mediation between the parties and advising the complainant on related issues.

3 Based on the recommendation of the Parliamentary Committee on Empowerment of Woman (14th Lok Sabha) on the subject "Plight of Indian Woman deserted by NRI husbands" which was discussed and deliberated upon by the Inter Ministerial Committee meeting held on 7th July, 2008 
c) Associating, networking with NGO's, community organisations in India and abroad and State Women Commissions for wider area coverage, so as to facilitate easy reach and provide support services

d) NRI Cell endeavor towards a coordinated response amongst various Government agencies/ organisations such as State Governments, The National Human Rights Commission, Indian Embassies and Mission, concerned Ministries etc.

e) Providing assistance to the aggrieved woman in litigation and other issues pertaining to the complainant/case.

f) Maintain a data bank of cases registered with NCW.

g) Seek reports from the State Government and other authorities on the complaints filed and action taken thereon.

h) To give advice and recommendations to the government on any policy or issue relating to the NRI marriages.

i) To analyze various legal treaties on the issue and advise the Government on the subject, wherever required.

j) To constitute an advisory committee of reputed advocates/NGOs, both in India as well as abroad, which shall periodically review the functioning of the cell, cases filed and policy issues?

k) To constitute a panel of experts to assist the aggrieved wife and rendering legal services and other assistance, including mediation and conciliation

1) Planning of training modules \& carrying out training on sensitization on the subject to the various agencies entrusted with the task of providing justice, viz. Judiciary, police, administration, etc.

m) To carry out awareness campaigns for the masses on the issue. For this, all the available media services would be utilised by the cell.

n) To encourage /support research and study in the related field like issues of grievances associated with dual citizenship, enactment of new legislation or signing of international treaties ,marriage laws of other countries ,etc .

o) To look into complaints and take suo-moto notice on any issue brought to the notice of the NRI Cell in accordance with Section 10 (1)(f) of the National Commission for Women Act, 1990 read with sub-section 4 of Section 10 and Section 8 of the Act.

p) Perform any other function as assigned to it by the Commission/Central Government. 


\section{- $\quad$ Success Story}

We can see the efficacy of NRIs Cell in the many of cases wherein remedy has been provided to the aggrieved. The brief of the case as mentioned below are some instances of successful story of NRI cell.

$\Rightarrow \quad$ In the case "Gurpreet Kaur" the complainant a poor Indian lady was married to a British citizen. Her husband and father in law bring her India on the false pretext of his father's ill health while her two minor children were in U.K. Her husband and father - in- law snatched her passport and went back and file divorce and custody of children cases in U.K courts. Even the police was reluctant to register FIR. Then the complainant approached the commission. Then the Commission approached the CPV Division of MEA, which helped her to get her new passport within a day. But the plight of the poor lady did not stop there. Her sponsorship for U.K was cancelled by her husband and was unable to travel there to contest the proceedings. The Commission then forwarded her case to the U.K courts and makes them aware of her inability to contest the proceedings. Her complaint was also forwarded to Consulate General of India, London. And by the efforts her case has been forwarded to a NGO, Good Human Foundation to contest the proceedings on behalf of the complainant in U.K courts.

$\Rightarrow \quad$ Another case is also important to discuss on the same issue as in the case "Suniana Chaudhary" the complainant has been subjected to severe mental and physical cruelty by her husband and in laws for years. She was even rescued from her matrimonial house by the New Zealand Police. Her husband has attained the custody of her minor children by producing a false medical certificate proving the complainant to be an insane. When the complainant came back to India the police was reluctant to register FIR as the threatening and harassment by her in laws still continues. Then the Commission intervened and the FIR was registered. And the Commission is still following up her complaint both in India and New Zealand.

$\Rightarrow \quad$ Fraudulent NRI marriage in our country is on rise. In this situation, women should take due care before solemnization of marriage with NRI's as she put to the suffering. Therefore, it is suggested that before taking any pleasant step close contact with NCW's coordination cell is expected all womenfolk concerned. Apex court, at its own end, has issued several judgements declaring that divorce under a marriage under the Hindu Marriage Act, 1955 cannot be granted by any court out of India. In Neeraja Sharaph v. Jayant V.Sharaph, the Supreme Court emphasized the need to consider a legislation safeguarding the interests of 


\section{Raval \& Dr. A.K Tripathi / Page 10-19}

women. Further, it suggested specific provisions to ensure that no marriage taking place in India, between an NRI and an Indian woman, is annulled by a foreign court. They have also recommended that in case of a divorce, adequate alimony be paid to the wife out of the share of the property of the husband both in India and abroad. The Court stated that the "decree granted by Indian courts may be made executable in foreign courts both on principle of comity and by entering into reciprocal agreements like Section $44-\mathrm{A}^{4}$ of the Civil Procedure Code which makes a foreign decree executable as it would have been a decree passed by that court"

This issue was also brought forth before the Rajya Sabha, Committee of Petitions in 2016. The Committee was advised that Section $14^{5}$ of the Foreign Marriage Act, 1969 has provisions to help women married to NRIs facing problems abroad. This section provides a mechanism for a marriage certificate being issued which "shall be deemed to be conclusive evidence of the fact that a marriage under this Act has been solemnized". However, on the face of it, a marriage certificate would only be a piece of paper unless further steps are taken to give it weight and make it recognised abroad. Looking at safeguarding rights of women from a legal perspective, there are adequate enabling legal safeguards securing the rights of women. Constitution of India, under Article 15(3) empowers the state to make any special provision for women. Further

4 Execution of decrees passed by Courts in reciprocating territory.-(1) Where a certified copy of a decree of any of the superior courts of any reciprocating territory has been filed in a District Court, the decree may be executed in India as if it had been passed by the District Court. (2) Together with the certified copy of the decree shall be filed a certificate from such superior court stating the extent, if any, to which the decree has been satisfied or adjusted and such certificate shall, for the purposes of proceedings under this section, be conclusive proof of the extent of such satisfaction or adjustment. (3) The provisions of section 47 shall as from the filing of the certified copy of the decree apply to the proceedings of a District Court executing a decree under this section, and the District Court shall refuse execution of any such decree, if it is shown to the satisfaction of the Court that the decree falls within any of the exceptions specified in clauses (a) to (f) of section 13.

Explanation I: "Reciprocating territory" means any country or territory outside India which the Central Government may, by notification in the Official Gazette, declare to be a reciprocating territory for the purposes of this section, and "Superior Courts", with reference to any such territory, means such courts as may be specified in the said notification.

Explanation II: "Decree" with reference to a superior Court means any decree or judgment of such court under which a sum of money is payable, not being a sum payable in respect of taxes or other charges of a like nature or in respect of a fine or other penalty, but shall in no case include an arbitration award, even if such an award is enforceable as a decree or judgment.

5 (1) Whenever a marriage is solemnized under this Act, the Marriage Officer shall enter a certificate thereof in the form specified in the Third Schedule in book to be kept by him for that purpose and to be called the Marriage Certificate Book, and such certificate shall be signed by the parties to the marriage and the three witnesses.

(2) On a certificate being entered in the Marriage Certificate Book by the Marriage Officer, the certificate shall be deemed to be conclusive evidence of the fact that a marriage under this Act has been solemnized, and that all formalities respecting the residence of the party concerned previous to the marriage and the signatures of witnesses have been complied with. 
under Article 51A (e), it is the duty of every citizen of India to renounce practices derogatory to the dignity of women.

It is submitted that social consent is the basis of law therefore; with legal awareness shape can be given to the law in an effective manner in order to maintain peace and harmony in the society to minimize conflicts. Given the scale of the problem and its domino effect on the deserted brides and their families, it is essential that holistic and planned efforts be undertaken. So the question is what next? One way is for the Union Government to enter into pacts with other countries to ensure that foreign courts refrain from granting divorce to people married under the Hindu Marriage Act, 1955. There is also a need for state laws for compulsory registration of marriages especially those with NRIs. Following the Punjab model, details of the whereabouts of the NRIs must be recorded. Further, strict penal provisions are needed to prosecute NRIs deserting their Indian brides. What is also needed is awareness generation which could be done through videos like the one by Punjab. These are some starting points for resolving this burgeoning issue. Therefore, there is an urgent need to follow the principle of comity to curb the issues relating to the NRI's marriage reciprocally at National and International level. Researchers lament that we are entering in highly technological age where there is no territorial boundaries . This world is a global village. Let's come forward and change ourselves to wipe out the tears of several who is victim of NRI marriage. Finally, we came to know that unless our mind set is changed, no concrete changes will be there. Our cultural and religious practices should not be nullified by economic development or growth. Let's be morally strong enough to protect and nurture our human tradition and humanistic cultural approach. Lastly, one should know that, faith is more important in life, not money in general, and particular to Holy Union. Let's be Indian by culture whenever we in the world.

\author{
Dr. Kaushik C. Raval \\ Dr. Anand Kumar Tripathi
}

